Jpn. J. Infect. Dis., 52, 1999

\title{
Detection and Identification of Adenovirus from Ophthalmological Specimens by Virus Isolation and PCR
}

\author{
Jumboku Kajiwara*, Mitsuhiro Hamasaki, Ryoichi Mori and Shinobu Oniki ${ }^{1}$ \\ Fukuoka Prefectural Institute of Health and Environmental Sciences, 39 Mukaizano, Dazaifu City, \\ Fukuoka 818-0135 and ' Oniki Eye Clinic, 712 Futsukaichi, Chikushino City, Fukuoka 818-0051
}

Communicated by Ryoichi Mori

(Accepted February 1, 1999)

Most epidemic kerato-conjunctivitises (EKCs) are caused by human adenovirus infections. Adenovirus is classified into 6 subgenera and 49 serotypes (1). Adenovirus types 3, 4, 8, 11, 19 and 37 are responsible for most eye infections. In laboratory diagnosis of adenoviruses, virus isolation using tissue culture is routine, but requires more than 2 weeks for isolation and typing. More recently, diagnosis by combination of polymerase chain reaction (PCR) coupled with restriction fragment length polymorphism (RFLP) has been introduced for identification of adenoviruses in the conjunctiva swabs.

In this study, we used PCR and RFLP to detect and identify adenoviruses on swabs from conjunctiva of 73 patients who had visited an eye clinic in Chikushino City in Fukuoka Prefecture and been diagnosed with EKC (71 cases), pharyngo-conjunctivitis (1 case) or acute conjunctivitis ( 1 case). The swab specimens were dissolved in $3 \mathrm{~m} l$ Hanks' solution containing $0.5 \%$ gelatin and centrifuged at $10,000 \mathrm{xg}$ for $10 \mathrm{~min}$. The supernatant was stock frozen at $-80 \mathrm{C}$ till the examination.

For virus isolation, Vero, FL, RD-18s and Hep-2 cells cultured in 96-well microplates were infected with the specimen in a volume of $25 \mu l /$ well and cultured for 1 week. The cultures negative for CPE were subcultured further. Specimens that failed to induce CPE after 4 subcultures were considered negative. Isolated adenoviruses were typed by using antisera provided by the National Institute of Infectious Diseases, Japan and the DENKA SEIKEN Co., Ltd., Tokyo.

PCR was conducted according to the method of Saito and Imagawa, (3). $200 \mu l$ of each specimen was centrifuged at $12,000 \mathrm{xg}$ for $30 \mathrm{~min}$. The pellet was dissolved in $100 \mu l$ of $0.31 \mathrm{mg} / \mathrm{ml}$ proteinase $\mathrm{K}, 0.5 \%$ Tween $20,1 \mathrm{mM}$ EDTA, and $10 \mathrm{mM}$ Tris- $\mathrm{HCl}$ $(\mathrm{pH} 8.3)$, then incubated at $55 \mathrm{C}$ for $1 \mathrm{hr}$. After the samples were heated at $95 \mathrm{C}$ for $10 \mathrm{~min}$, DNA was extracted. Nested PCR using the primers shown in Table 1 (external primer pairs were AdTU7 and AdTU4', and internal pairs were AdnU-S' and AdnU-A) was conducted. Both the first and second PCR amplifications consisted of 36 cycles of denaturation at $94 \mathrm{C}$ for $1 \mathrm{~min}$, annealing at $50 \mathrm{C}$ for $1 \mathrm{~min}$ and elongation at $72 \mathrm{C}$ for $2 \mathrm{~min}$; after the second amplification the samples were incubated at $72 \mathrm{C}$ for $7 \mathrm{~min}$ for completion of the elongation reaction. The amplified materials were digested with
EcoT14I, HaeIII, or HinfI and electrophoresed in 3\% agarose gel (Fig. 1).

The results are summarized in Table 2. Virus isolation in culture and serotyping identified adenoviruses from 28 specimens: eight Ad3, one Ad8, one Ad11, fifteen Ad19, and three Ad37 specimens. PCR-RFLP identified adenoviruses from 54 specimens: nine Ad3, eleven Ad8, one Ad11, twentyfour Ad19, and nine Ad37 specimens. The data on all specimens agreed perfectly between the two methods performed. The PCR-RFLP method required 3 days for a complete analysis. The positivity was $74 \%$ (54/73) for PCR-RFLP, and $38.4 \%$ (28/73) for virus isolation and serotyping. For B subgenera Ad3 and Ad11, the sensitivities of the two methods were comparable, while for D subgenera Ad8, Ad19 and Ad37 (particularly for Ad8) the virus isolation in culture was very inefficient. In neutralization, Ad19 and Ad37 showed cross reactivity, but in PCR-RFLP the two viruses were clearly distinguished (Fig. 1). Our data thus demonstrated the usefulness of PCR-RFLP for the laboratory diagnosis of adenoviruses. However, we should also be aware of the limitations of the PCR method, e.g., PCR detects only a fragment of the virus genome and detects viruses only if they have a sequence suitable for the primers. Because virus isolation and PCR-RFLP provide complementary information, both should be used for the virus surveillance.
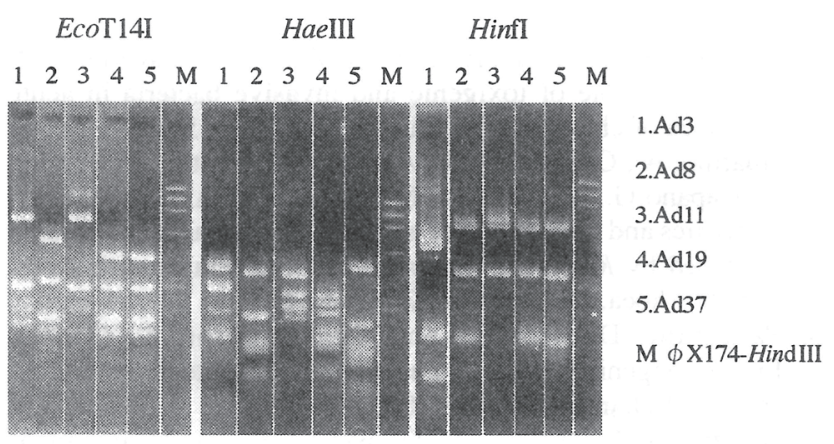

Fig. 1 PCR products digested by restriction enzymes

Table 1 Primers for nested PCR of Adenovirus

\begin{tabular}{cccc}
\hline Primers & Nucleotide Position $^{\mathrm{a}}$ & Sequence & PCR Product(bp) \\
\hline AdTU7 & $20,734-20,753$ & 5'-GCCACCTTCTTCCCCATGGC-3' & 1,004 \\
AdTU4' & $21,718-21,737$ & 5'-GTAGCGTTGCCGGCCGAGAA-3' & \\
AdnU-S' & $20,743-20,762$ & 5'-TTCCCCATGGCNCACAACAC-3' & 956 \\
AdnU-A & $21,679-21,698$ & 5'-GCCTCGATGACGCCGCGGTG-3' & \\
\hline
\end{tabular}

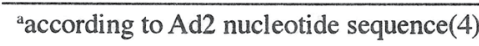

Table 2 Detection of Adenoviruses

\begin{tabular}{lccccccc}
\hline & Positive Specimens(\%) & Ad3 & Ad8 & Ad11 & Ad19 & Ad37 & negative \\
\hline Virus Isolation & $28(38.4)$ & 8 & 1 & 1 & 15 & 3 & 45 \\
PCR-RELP & $54(74.0)$ & 9 & 11 & 1 & 24 & 9 & 19 \\
\hline
\end{tabular}

\footnotetext{
*Corresponding author (Fax : +81-92-928-1203)
} 
The eye swabs used in this study were collected by the National Epidemiological Surveillance of Infectious Diseases.

\section{REFERENCES}

1. Schnurr, D. and Dondero, M.E. (1993): Two new candidate adenovirus serotypes. Intervirol, 36, 79-83.

2. Aoki, K., Isobe, K. and Ohono, S. (1994): Nationwide surveillance program of epidemic conjunctivitis in Japan. 309-316. In A.A. Bialasiewics and K.P. Schaal (eds.), Infectious diseases of the eye. Butterworth Heinemann, Boston.

3. Saitoh-Inagawa, W., Oshima, A., Aoki, K., Itoh, N., Isobe, K., Uchino, E., Ohono, S., Nakazima, H., Hata, K. and Ishiko, H. (1996): Rapid diagnosis of adenoviral conjunctivitis by PCR and restriction fragment length polymorphism analysis. J. Clin. Microbiol., 34, 2113-2116.

4. Chroboczek, K., Bieber, F. and Jackrot, B. (1992): The sequence of the genome of adenovirus type 5 and its comparison with the genome of adenovirus type 2. Virology, 186, 280-285. 